\title{
Internal and External Coordinated Open Innovation Ecosystems: Concept Building and Applying to Shanghai Zizhu International Education Park
}

\author{
Haiyan Yan ${ }^{1}$, Linlin Wang ${ }^{2, *}$, Xinyue Yan $^{3}$ and Qiongbo Zhai ${ }^{1}$ \\ 1 School of Management, Shanghai University of International Business and Economics, \\ Shanghai 201620, China; yhy@suibe.edu.cn (H.Y.); 17329006@suibe.edu.cn (Q.Z.) \\ 2 Institute of Ecology and Sustainable Development, Shanghai Academy of Social Sciences, \\ Shanghai 200020, China \\ 3 School of Finance, Shanghai University of International Business and Economics, Shanghai 201620, China; \\ 17013041@suibe.edu.cn \\ * Correspondence: wanglinlin@sass.org.cn or wanglin9004@163.com
}

Received: 31 August 2020; Accepted: 12 October 2020; Published: 13 October 2020

\begin{abstract}
In an environment marked with phenomena such as globalization and creation, open innovation is critical for universities to cooperate with external resources and meet the requirements of the era. To investigate open innovation ecosystem of higher education, we use secondary data and interviews to analysis interactive model of Zizhu International Education Park from both internal and external perspectives. The analysis result suggests that the open innovation ecosystem could have positive effects on the development of higher education. It can contribute to deepening the integration of production, teaching, and research; improve the efficiency of scientific research transformation; and use this part of the income to supplement school funding. While the university-industry collaborative relationship could also be a limiting factor for it.
\end{abstract}

Keywords: open innovation; ecosystem; higher education

\section{Introduction}

With rapid globalization, a nations' competitiveness depends on developing and continuing to improve people's knowledge and skills through education [1]. There has been a lot of discussion about whether universities can achieve their third mission of social engagement with the surrounding society, in addition to research and teaching [2-4]. As one of the providers in public education, higher education institutions play important roles in society as producers and transmitters of knowledge. In order to cultivate innovative talents for the era of innovative economy, the universities should be aware their products are the training of creative talents, who are the important foundation for human economics and social development. With the increasingly changing external environment, more and more higher education institutions are following the trend of "open innovation" in the global market through adopting a broader mind to cooperate with public sectors and profit organizations at home and abroad. It contributes to an active dialog and effective cooperation among universities, industry, government, and society.

The proposal of open innovation has promoted the transformation of the innovation paradigm in theory and industry and shifted innovation from traditional closed to open [5-7]. Open innovation is a rational strategy for any organizations, which is a worldwide phenomenon [8,9] A significant body of published work already exists on this subject, including case studies and lessons learned, and organizations formed to provide advice and guidance [10]. However, most of current research studied open innovation from the perspective of enterprise to jointly develop new products and 
services. In recent years, many scholars started to adapt this theory to education development as the global competition is getting fiercer in the market-oriented education system. For example, some research has illustrated that university-industry-government partnership linkages are extremely important mechanisms for shaping the growth and sustainable development of higher education [11,12]. Building of open innovation ecosystem of higher education is bilateral interaction. On the one hand, it is a critical approach for universities to obtain more social resource to support their sustainable development. Studies have shown that an open innovation ecosystem is helpful for the improvement of achievements in scientific research, the quality of students, and school industry return, which are the key factors affecting competitiveness of the schools [13]. On the other hand, it is also an effective approach for enterprises to acquire external resources for their research and development activities [14,15].

Although more and more studies have been conducted on the evolution of university-industrygovernment relations, the current focuses are mainly on the generation and development of academic capacity of human resource transfer, commercialization of property rights, informal interaction, and scientific publications [16-18]. There are few researches in studying collaborative mechanism of various participators within their environment and its outcome. In their research, Nam et al. analyzed the cooperation between government, university, and company in South Korea using Triple Helix's statist model [19]. However, they focused on evaluating how resources of universities and government-initiated policies affect the achievement of the university-industry collaboration. The open innovation ecosystem of higher education by in-depth discussion on the university-industry-government interactions is still lack of research, especially based on the case of China. Therefore, this paper aims to bridge the gap and investigate the structural relationship and resource interaction behavior of the open innovation ecosystem with enterprises, universities, and local government as the main body, in order to explore the key factors restricting the collaborative innovation of university -industry-government cooperation.

The paper adopts case study method to explore a typical education park—the Shanghai Zizhu International Education Park (SZIEP). This education park is one of the globally influential higher education agglomeration zones and demonstration zones for the integration of industry, academia, and research in China. It seeks to build its own innovation ecosystem, including functions such as creativity, entrepreneurship, financing and investment, and innovation. At the same time, it embeds top universities, research institutions, government resources, strategic business partners, capital funds, customers, and employees into the ecosystem. This paper attempts to analyze the knowledge sharing system of SZIEP from the perspective of open innovation ecosystem, in order to explain how SZIEP can maintain its competitive advantage in the era of globalization and make contributions to the development of a knowledge, innovation-driven economy.

The organization of the paper is as follows. In Section 2, we introduce the research status of the open innovation ecosystem of higher education through a literature review. Then, Section 3 gives an introduction of the research methodology. In Section 4, we use systems thinking to analyze the interactions among main participants in the open innovation ecosystem of higher education and present a causal cycle diagram analysis of the open innovation ecosystem. Section 5 provides our conclusion.

\section{Literature Review}

\subsection{The Concept of an Open Innovation Ecosystem}

Open innovation has attracted increasing attention both practically and academically since its concept was firstly put forward by Chesbrough in 2003 [20]. According to Chesbrough, greater openness to external sources of knowledge contributes to innovative output [21-23]. This openness encourages the flow of ideas, knowledge, and information between businesses [24,25]. It is proved in current studies that organizations are paying more attention to "open innovation" through a more open model that involves working extensively with outside agents and commercializing ideas in a variety of 
different ways rather than relying on internal $R \& D[21,26]$. The use of external resources is a powerful tool for enterprise R\&D and innovation [27].

In recent years, the research on open innovation has expanded from the binary transfer of ideas, knowledge, and information to the ecosystem level. The innovation ecosystem is analogous to biology [28]. It is made up of different stakeholders who are linked together through competition and partnerships to create value together by using an open method [29]. The subject includes the physical resources and human resources of the stakeholders that participate in the ecosystem (university, college, school of business, commercial companies, venture capitalists, university of technology institute, etc.) [30]. Physical resource includes capital, equipment, materials, facilities, and so on, while human resources mean students, teachers, industry representatives, etc.

There is a large amount of material, energy, and information exchange between the interior and exterior environment, which assists with keeping the balance of efficiency and stability within the ecosystem [31]. The relationships within the ecosystem can be tangible in a monetary way and, in the meantime, intangible referring to cultural and social segregations [32]. In an innovation ecosystem, companies can take a competitive strategy: they compete for market share but at the same time cooperate to defend, develop, and grow their ecosystems [33]. A single organization can participate and play different roles in several interconnected ecosystems [34]. The innovation ecosystem allows companies to create value, which a single company cannot create alone $[35,36]$.

\subsection{The Open Innovation Ecosystem of Higher Education}

In today's globalized society, institutions of higher education recognize that partnerships and engagement with the rest of the world serve them well. In addition to the increase in open innovation in private sectors [37,38], more and more institutions of higher education are pursuing open innovation programs [39,40]. Universities have become proactively engaged in multiple areas, from technology transfer to knowledge co-creation [41]. Open innovation in the public sector aims at improving service performance, which is different from that in the private sector [1]. However, while every country spends a large budget on public education, national education systems are often challenged by a lack of vision, good policies, and resources.

In order to overcome these constraints, many university science parks sponsored and led by local governments have emerged in China to promote the cooperation and innovation between university and industry. These regional university science parks often keep a relationship of imitation and competition, such as the Songjiang University Town, located in the suburb of Shanghai in Songjiang District; Shenzhen University Town, situated in the Nanshan District of Shenzhen; and Zhuoda University Town in the eastern suburban of Beijing [42]. Taking a hybrid approach, the research finds the local government has played a rich role in promoting direct links between universities and industry based on an in-depth case study of the Suzhou Dushu Lake Science and Education Innovation District in China [42]. However, while higher education has entered an era of open innovation, there is still a lack of clarity on how to strengthen partnerships between different stakeholders in their respective environments. This requires a systematic way of thinking to analyze this complex ecosystem $[43,44]$.

Therefore, in this study, we use systems thinking to illustrate multi-stakeholder collaboration within an ecosystem from both internal and external perspectives based on interviews and secondary data collected of SZIEP, which makes us can systematically analyze the ecosystem of open innovation in higher education. The casual loop diagram has the advantage of providing a common language to analyze the dynamic interactions of the open innovation ecosystem over time [45].

\section{Research Methodology}

\subsection{Qualitative Data Analysis and Case Selection}

In the study of social sciences, a case-study approach is characterized by concentrating on investigating a phenomenon within its background by obtaining data, so as to provide an in-depth 
investigation and analysis of the phenomenon itself [46]. When conducting a case study research, the case selection is purposeful and relates to replication using rather than sampling logic [46,47]. We also use the Triple Helix model as the neo-institutional model of arrangements among different stakeholders in case study analysis, by addressing the relevance of the three major dimensions of the model [48].

Four accounts for choosing Shanghai Zizhu International Education Park (SZIEP) for our study are expressed as follows. Firstly, it is a globally recognized bourn for transnational education and research activities (i.e., Sino-foreign cooperative universities, overseas campus for foreign universities, and Sino-foreign universities with high autonomy) and executive development through internationally recognized institutions from around the globe. Hence, it builds close affinity with universities research institutions. Secondly, it was established by the People's Government of Shanghai Minhang District (PGMD) jointly with Zizhu National Hi-Tech Industrial Development Zone (ZIZHU), with an advantage to cooperate with government and enterprises. Thirdly, industry has played the important role, which produces a significant impact on SZIEP's innovation ecosystem structure. Market-orientation is an important consideration for SZIEP to introduce its settlement agency. Fourthly, unlike what has been studied in previous work, the interaction and cooperation among the main participators in the open innovation ecosystem is a new mode. To sum up, creativity, inter-cooperation, financial supports, ventures, and innovation have all been underdiscussed via the studies. In general, extremely abundant contents have been provided to disclose the response relationship and dynamics in the open innovation ecosystem.

\subsection{Introduction of SZIEP}

SZIEP is located at ZIZHU—-the geographic center of Shanghai Municipality, Minhang District. ZIZHU serves as an important hub for outbound traffic, a major industrial base, and an emerging area for investment in the science and technology sector, including being a developing site for aeronautics. ZIZHU has five functional areas, including a universities area (Shanghai Jiaotong University and East China Normal University), a research and development base with nearly 500 organizations and anchoring 15 national key laboratories, the Zizhu peninsula community, a living area, and SZIEP (Figure 1).

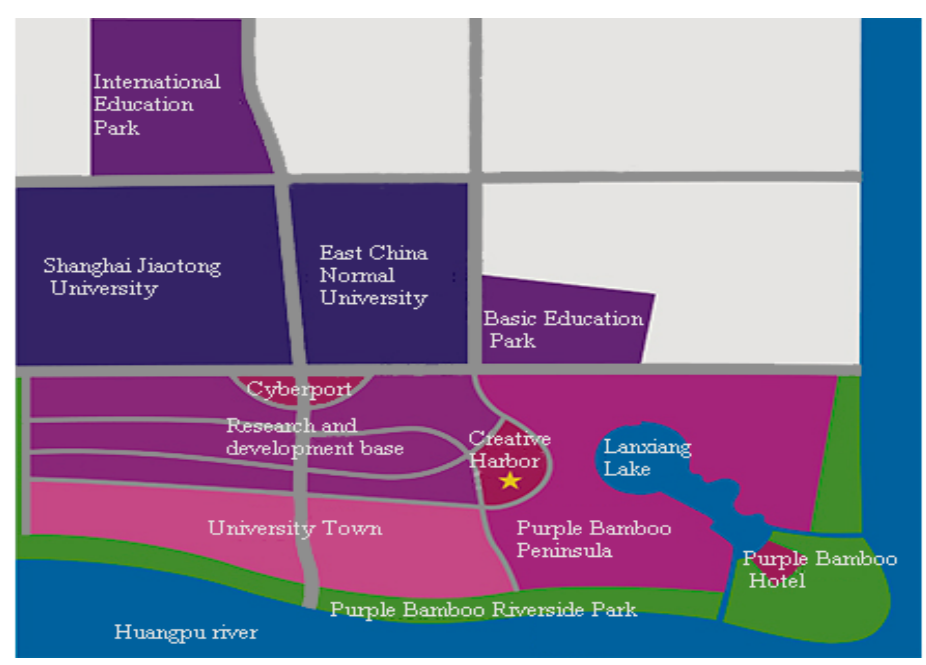

Figure 1. Overview of the functional area in the Zizhu National Hi-Tech Industrial Development Zone (ZIZHU).

SZIEP has been identified as a pilot program, considered with a view to gradual and comprehensive national education reform. As Table 1 shows, by the end of May 2020, a total of six schools including Institute of Cultural and Creative Industry (Shanghai Jiao Tong University, China-University of 
Southern California, USA), Asia Europe Business School (East China Normal University, China-Emlyon Business School, France), Joint Translational Science and Technology Research Institute (East China Normal University, China-University of Haifa, Israel), Shanghai International College (Beijing Film Academy, China), Huaer Zizhu Lemania College (No. 2 High School of the East China Normal University, China-Lemania Swiss Group of Schools, Switzerland), and Shanghai Zizhu International Education College have moved into the park. Each education institution has a specific talent orientation to support the nation's strategic emerging industries and modern services.

Table 1. Higher education institutions in Shanghai Zizhu International Education Park (SZIEP).

\begin{tabular}{|c|c|c|c|c|}
\hline & Institute & $\begin{array}{c}\text { Time of } \\
\text { Establishment }\end{array}$ & $\begin{array}{l}\text { Co-Construction } \\
\text { Institution }\end{array}$ & $\begin{array}{c}\text { Student Educational } \\
\text { Orientation }\end{array}$ \\
\hline 1 & $\begin{array}{l}\text { USC-SJTU Institute } \\
\text { of Cultural and } \\
\text { Creative Industry }\end{array}$ & 2015 & $\begin{array}{l}\text { University of Southern } \\
\text { California (USA) } \\
\text { Shanghai Jiao Tong } \\
\text { University (China) } \\
\text { PGMD, Shanghai } \\
\text { ZIZHU }\end{array}$ & $\begin{array}{c}\text { Training talents in art, } \\
\text { technology, } \\
\text { and management }\end{array}$ \\
\hline 2 & $\begin{array}{c}\text { Asia Europe } \\
\text { Business School }\end{array}$ & 2015 & $\begin{array}{c}\text { East China Normal } \\
\text { University (China) } \\
\text { Emlyon Business School } \\
\text { (France) } \\
\text { PGMD, Shanghai } \\
\text { ZIZHU }\end{array}$ & $\begin{array}{l}\text { Training talents in } \\
\text { international and innovative } \\
\text { management for the } \\
\text { construction of countries } \\
\text { along the "Belt and Road" }\end{array}$ \\
\hline 3 & $\begin{array}{l}\text { Joint Translational } \\
\text { Science and } \\
\text { Technology } \\
\text { Research Institute }\end{array}$ & 2016 & $\begin{array}{l}\text { East China Normal } \\
\text { University (China) } \\
\text { The University of Haifa } \\
\text { (Israel) } \\
\text { PGMD, Shanghai } \\
\text { ZIZHU }\end{array}$ & $\begin{array}{l}\text { Training talents in data } \\
\text { science, neuroscience, } \\
\text { biomedicine, and } \\
\text { ecological environment. }\end{array}$ \\
\hline 4 & $\begin{array}{c}\text { Shanghai } \\
\text { International } \\
\text { College (Beijing } \\
\text { Film Academy) }\end{array}$ & 2016 & $\begin{array}{c}\text { Beijing Film } \\
\text { Academy(China) } \\
\text { PGMD, Shanghai } \\
\text { ZIZHU }\end{array}$ & $\begin{array}{l}\text { Training talents with } \\
\text { creativity, technology, and } \\
\text { management of the film and } \\
\text { television industry. }\end{array}$ \\
\hline 5 & $\begin{array}{c}\text { Huaer Zizhu } \\
\text { Lemania College }\end{array}$ & 2019 & $\begin{array}{l}\text { East China Normal } \\
\text { University, China } \\
\text { Lemania Swiss Group of } \\
\text { Schools, Switzerland } \\
\text { PGMD, Shanghai } \\
\text { ZIZHU }\end{array}$ & $\begin{array}{l}\text { Training talent in } \\
\text { pre-university education. }\end{array}$ \\
\hline 6 & $\begin{array}{l}\text { Shanghai Zizhu } \\
\text { International } \\
\text { Education College }\end{array}$ & 2012 & $\begin{array}{l}\text { PGMD, Shanghai } \\
\text { ZIZHU }\end{array}$ & $\begin{array}{l}\text { Training talents in } \\
\text { pre-university education, } \\
\text { elite education, and } \\
\text { undergraduate } \\
\text { general education }\end{array}$ \\
\hline
\end{tabular}

Note: "PGMD" and "ZIZHU" refers to "People's government of Minhang district" and "Zizhu National Hi-Tech Industrial Development Zone", respectively.

\subsection{Data Collection}

The exhaustive appreciation of structure, operation, and collaboration in SZIEP and the business and innovation background of the ZIZHU should be taken due to the nature of our study. Therefore, we collected secondary data from the official websites of SZIEP, its settlements institutions, ZIZHU, and other official news reports from the Internet. This sufficient content enables us to give an in-depth comprehension of the SZIEP itself and to triangulate perspective across disparate roles. Then, as a preliminary phase of the work, four unstructured interviews of the managers in SZIEP were conducted to obtain more information for systematic investigation. 


\section{Findings}

Similar to other ecosystems, open innovation is also controlled both by external and internal factors. From an internal perspective, SZIEP uses resources, policies, and systems to continuously innovate and provides a micro-innovation ecosystem for its settled institutions. From an external perspective, SZIEP collaborates with various ecological entities based on innovative environmental factors. Therefore, in this section, we will first discuss the open innovation of SZIEP from both internal and external perspective. Then, based on the analysis, we conclude the general dynamic interactions in the innovation ecosystem of higher education.

\subsection{Internal Open Innovation Ecosystem of SZIEP (Micro-Perspective)}

SZIEP is especially characterized as innovation-oriented, as a joint venture between PGMD and the national-grade ZIZHU. According to its autologous resources and capabilities, SZIEP operates as an orchestration who places emphasis on a fraction of the innovation process and depends on partners to play the main role in obtaining the rest, not as an integrator or licensor. It observes the principles of "platform utilization, autonomous operation, resource sharing, research integration" in pursuing collaboration opportunities for "Sino-foreign cooperation in running schools". SZIEP provides support to each program in accordance to its status, impact, size, and sustainability. However, it will not interfere with Sino-foreign academic programs, and each will be independent of all the others. Decisions regarding forms of cooperation, curricula, delivery of courses, internal administration, etc., will be solely those for the interested parties in the academic programs to make. SZIEP supports the school-run projects through the methods of one-time subsidies and rent subsidies to provide teaching, scientific research, and infrastructure leasing services for projects already settled in the park.

Figure 2 shows an internal open innovation ecosystem of SZIEP. Inside the SZIEP, the educational institutions have a high degree of collaboration and resource sharing. On one hand, by emphasizing efficient and intensive land utilization, all of them can share public service areas, service facilities, student residences, restaurants, and sports venues provided by the SZIEP. Non-profit educational institutions including the Institute of Cultural and Creative Industry, Asia Europe Business School, Joint Translational Science and Technology Research Institute, and Shanghai International College even can share teacher resources and scientific research resources. It means students can choose courses across the school, and teachers are allowed to teach in different schools. Resource sharing is also reflected in the collaboration between non-profit and for-profit educational institutions. As a for-profit educational institution, Shanghai Zizhu International Education College can carry out various types of undergraduate-level international cooperation courses and on-the-job training programs with other institutions.

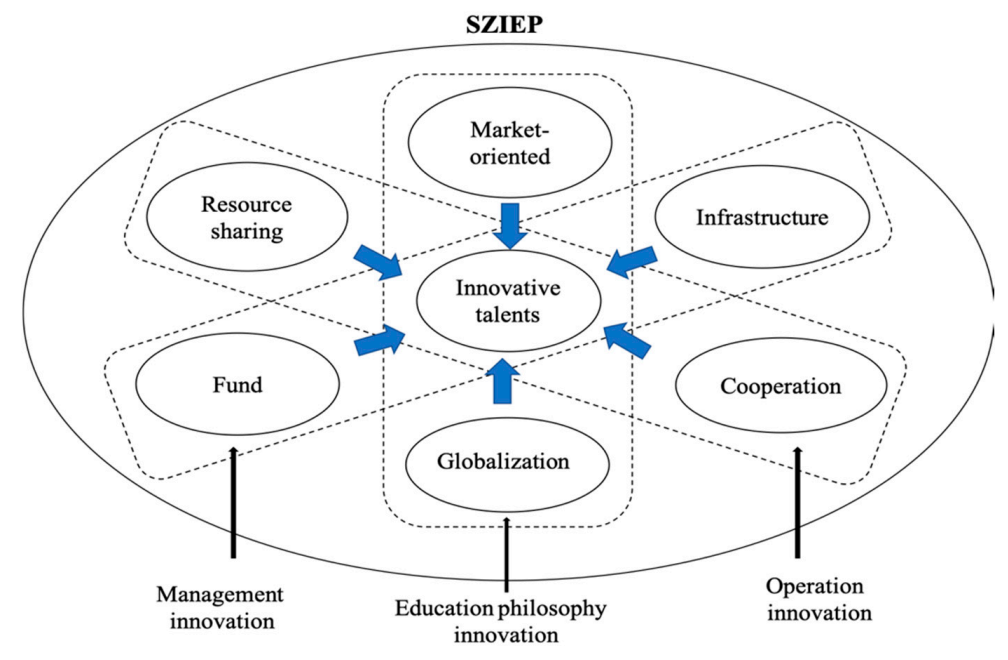

Figure 2. Internal open innovation ecosystem of SZIEP. 


\subsection{External Open Innovation Ecosystem of SZIEP (Macro-Perspective)}

In the external innovation ecosystem, SZIEP undertakes the function of innovation ecological subjects and collaborates with government, parent universities, research institutions, enterprises, etc. Figure 3 shows the external open innovation ecosystem of the SZIEP. Since many higher education organizations in the park have to rely on both maternal universities and related institutions in the park, this is neither a new university in the full sense nor a secondary college within the university in the traditional sense. It is a new type of higher education organization that was born in the interaction of government, industry, university, and academic institutions.

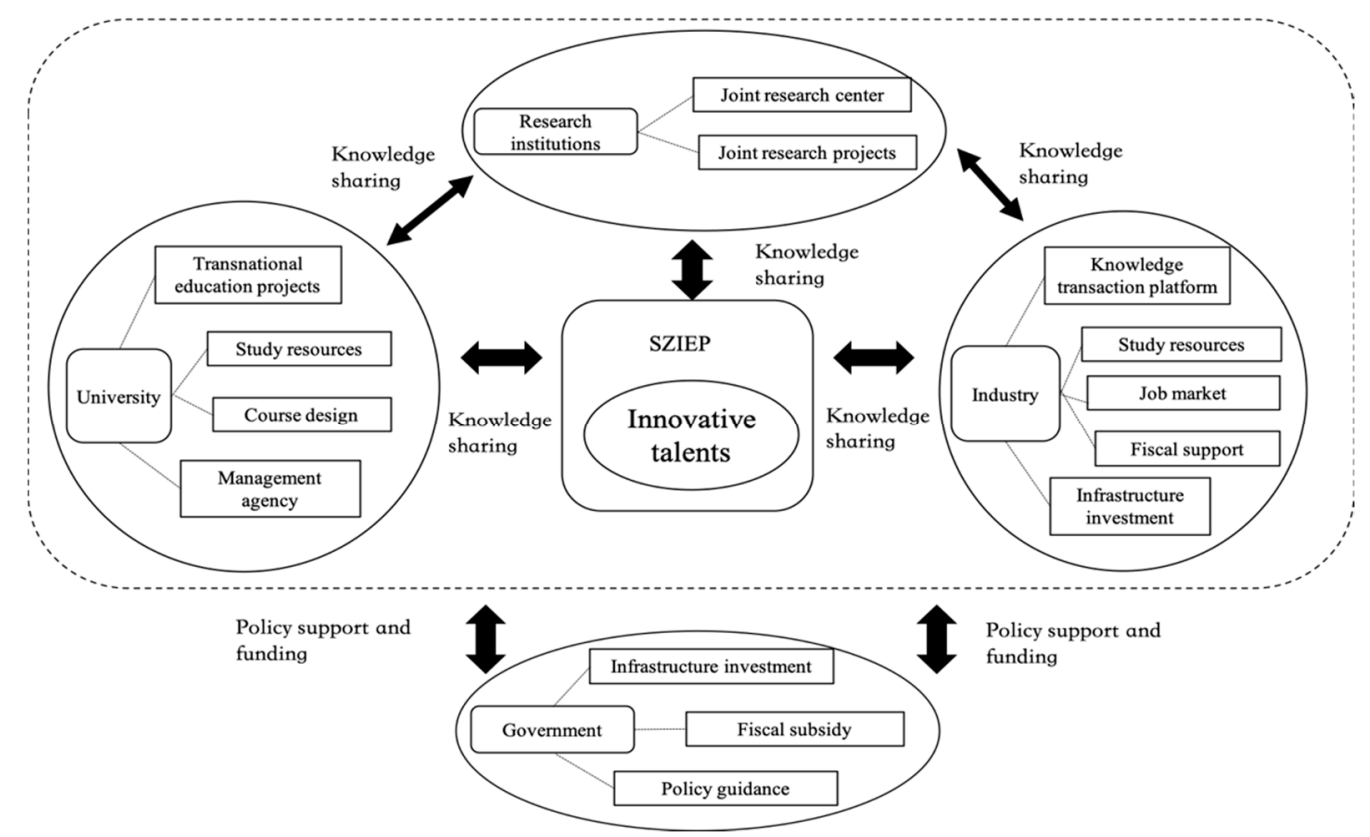

Figure 3. External open innovation ecosystem of SZIEP.

As a venture of PGMD and ZIZHU, SZIEP has maintained close contact with the local government. In actual operations, PGMD and ZIZHU, jointly funded the establishment of Shanghai Zizhu International Education Park Co. Ltd. as the construction unit and operating body of SZIEP. Shanghai Zizhu International Education Park Co. Ltd. takes charge of the development plans, constructs, and manages of the SZIEP. The education park is a mixed-ownership institution. The funds required are partly from government input, partly provided by Zizhu Hi-Tech Zone, and partly funded by participating universities and social organizations. It is a clear and significant impact of government and its policies on all ends of higher education, notably in a tightly regulated environment such as China.

Compared with the policy supports from government, universities and research institutions contribute more on providing education resources, such as transnational education projects, study resource, course design, and teaching management. For example, in the non-profit educational institutions such as Asia Europe Business School, in order to reach the international standards in terms of the teaching quality, all faculty has been recruited by the home and foreign host universities. Besides the international teaching resource, most settled institutions in SZIEP provide exchange programs so that their students can study at foreign host universities for one semester or one year. Beyond that, some of them also provide special degree programs such as $2+2$ or $3+1$ programs. Enrolled students may study in a Chinese campus during the first two or three years; afterwards, they may continue their academic study in their foreign host university, taking credits from both the cooperative university in China and the foreign institution. This kind of exchange or study experiences becomes a bonus for students, especially when they decide to further their study at abroad. 
Industry also has a pivotal impact on the open innovation ecosystem of SZIEP. It participates in the construction of the SZIEP, not only provides financial support, but also offers scientific research and industrial resources for the SZIEP to support the development of education. The R\&D base of ZHIDZ is home to enterprises in six emerging strategic industries such as integrated circuits and software, new energy, aviation and astronautics, digital content, new materials, and life sciences. It primarily features regional headquarters, $R \& D$ centers, and venture capital firms. The Hi-Tech Zone features a nucleus of global, Asia-Pacific, or China R\&D headquarters of Fortune 500 companies including Coca-Cola, Intel, Microsoft, ExxonMobil, GE, Omron, and Toray; additionally, it is the site of national-level ventures such as GE-AVIC Civil Avionics Systems Company Limited, COMAC Shanghai Aircraft Customer Service Co. Ltd., and AVIC Commercial Aircraft Engine Co. Ltd. At present, ZHIDZ has witnessed the establishment of the headquarters or R\&D centers of nearly five hundred high-tech enterprises with an approximate total of 20,000 scientists and engineers.

In the case of SZIEP, integration of industry and education is achieved in various methods. On one hand, enterprises can provide internship opportunities for students, establish R\&D and practical training bases for the universities in the park, drive the development of emerging industries, and create a "deep-integration" demonstration zone that is compatible with high-tech functional areas. For instance, the Asia Europe Business School's Career Development Center (CDC) of Asia Europe Business School provides personalized consultation and employment assistance through cooperating closely with the local and multinational corporations and a great college alumni association. The cooperation provides students with a lot of valuable service, such as professional career mentorship and training. The companies can also offer employer presentations, internship programs, and job postings. On the other hand, SZIEP can also in turn provide knowledge and talent training for industry development. For example, Shanghai Jiao Tong University and Kedge Business School jointly establish the SJTU-Kedge Global MBA Programme to meet the internationalization of local companies together with the localization of MNCs.

\section{Discussion: Open Innovation, Ecosystem, and System Dynamic Feedback Loop}

\subsection{Systems Thinking of the Open Innovation Ecosystem of Higher Education}

Based on the discussion above, a general casual loop diagram for the open innovation ecosystem in higher education is given in Figure 4. It aims to help understand the relationships that exist between the university, industry, and government and the way they interact and cooperate with each other to enhance the sustainable development of open innovation ecosystem of higher education. As Figure 4 shows, there are five reinforcing feedback loops and one balancing feedback loop in the open innovation ecosystem of higher education.

Loop R1 demonstrates a feedback loop which enhances the academic support at home and abroad, such as the cooperation with other universities and research institutions. With the increasing competitiveness of the education clusters, education institutions will increase their academic support for the resident institutions. They will put much more effort and money to improve the education equality, such as construction of teaching staff and the curriculum design. This will in the future increase the academic reputation. Then, the increase in the academic reputation will enhance the competitiveness of education clusters, which will be helpful for getting more academic support eventually. Loop R2 illustrates a show of a reinforcing feedback loop for government's open innovation support. The improvement of academic reputation can attract more excellent students. Therefore, the local education level will increase, and the local education system can deliver more talents for local economic and social development. Improvement of economy and society will contribute to the development of local government, which can attract more public policy and government financial support for education. With the more aggressive support from government, education institutions can better improve teaching environment and develop teaching resource, which can promote the growth of academic reputation. Loop R3 demonstrates the positive impact of industry 
support on the sustainable development of the open innovation ecosystem in higher education. Enhanced education quality drives more industrial talent reserves, which will in the future increase the industry income. Then, more industry income will bring more industry support and better investment that generates a reinforcing feedback to investment on open innovation in the education parks. Loop R4 illustrates the reinforcing effect of variety of open innovation on the whole open innovation ecosystem. More investment on open innovation will increase the capacity of education institutions to develop more open innovation projects, which will increase the achievements of scientific research and then obtain more support from academic institutions. Loop R5 focuses on the positive interactive relationship between education quality and achievements in scientific research.

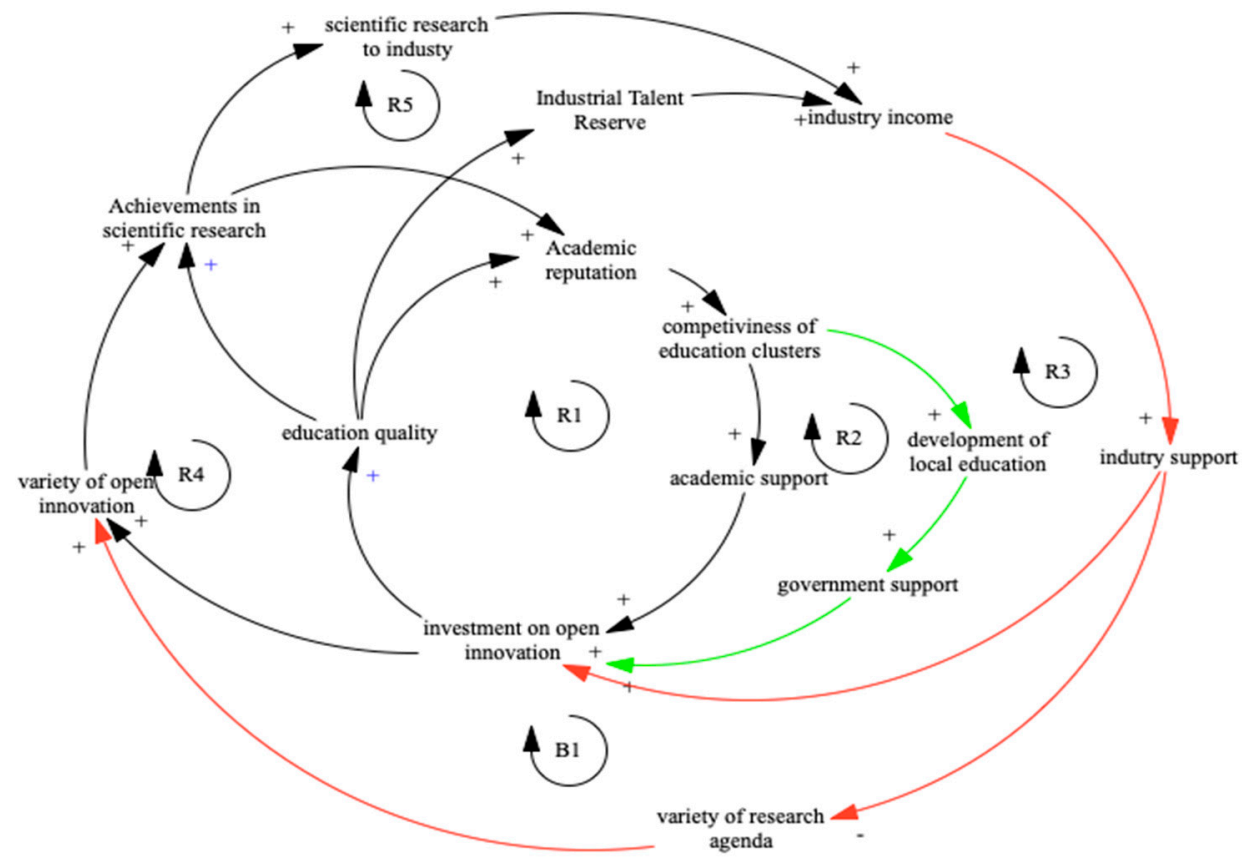

Figure 4. A casual loop diagram for the open innovation ecosystem in higher education; Note: The causal link points from cause to effect, while positive link (+) means change in same direction and negative link (-) means the opposite. Loop label $\mathrm{R}$ represents reinforcing loop that exaggerates what happens, and label B represents balancing loop that fill the gap existed.

Besides the positive effects of an open innovation ecosystem on higher education, Loop B1 shows the negative impact of university-industry collaboration on the sustainable development of higher education. Cooperation between enterprises and universities is often in specific fields. The increase in research projects entrusted by the enterprises will limit the diversity of research agenda. Decreasing of the diversity of research agenda will reduce the variety of open innovation. Then, achievements in scientific research will decrease, which will in the future reduce the industry income. Then, less industry income will lead to less industry support that will create a balancing feedback to investment on open innovation in the education parks.

\subsection{Conclusion and Future Study}

In this research, we analyze the open innovation ecosystem of higher education based on the SZIEP case from the perspective of systems thinking. The analysis result suggests that the open innovation ecosystem could have positive effects on the development of higher education. From the aspect of universities and research institutions, it can contribute to deepening the integration of production, teaching, and research; improve the efficiency of scientific research transformation; and use this part of the income to supplement school funding. For companies, this open innovation ecosystem can effectively improve their technological innovation ability at a lower cost. For the governments, 
building a sustainable open innovation ecosystem for higher education can bring considerable and long-term economic and social benefits. While the university-industry collaborative relationship could also be a limiting factor for the development of open innovation ecosystem. Excessive cooperation between universities and enterprises might limit the diversity of scientific research. Meanwhile, it also has a negative impact on enterprises. Taking the dual-functional teachers who are employed from enterprises in universities as an example, it is difficult for them to adjust the conflict between their own work and teaching tasks. In conclusion, open innovation of higher education not only helps to supplement the scientific research funds but also promotes the transformation of scientific research achievements and the improvement of scientific research teaching level. Thus, it will greatly improve the academic competitiveness of universities and research institutions. At the same time, this open innovation model can also provide enterprises with professional knowledge and technology, as well as professionals and researchers who master this knowledge and technology, so as to improve the business transformation ability of knowledge and enhance its economic value.

This study contributes both at theoretical and practical levels. At the theoretical level, it explores the open innovation ecosystem of higher education from a systems thinking approach, which can be used to enhance our understanding about university-industry-government relationship and open innovation. At the practical level, it outlines the key factors affecting the open innovation ecosystem of higher education. This could provide suggestions for the decision-makers on how to enhance the growth and sustainable development of open innovation ecosystem. For example, the decision-makers of higher education institutions should take their education missions into consideration when integrating open innovation. The main contribution of our research is that it provides a new theoretical basis and structural analysis framework for exploring the advantages and constraints of government-university-industry collaboration more effectively, so as to promote the collaborative innovation and development of city industry-university research.

There are also several limitations in this study, which provide some opportunities for future research. First, constrained by limited interviews on the managers from SZIEP, there lacks detailed information on the collaboration between SZIEP and industry. Thus, future study could conduct more interviews on the participants from other departments such as teaching teams and R\&D department of enterprises. Second, we analyzed the open innovation system of higher education by a qualitative approach. It is difficult to verify whether the open innovation ecosystem leads to higher performance. Therefore, future research on open innovation ecosystem of higher education could consider the performance management.

Author Contributions: Conceptualization, H.Y. and L.W.; methodology, H.Y. and L.W.; data curation, X.Y. and Q.Z.; writing-original draft preparation, L.W.; and Q.Z.; writing-review and editing, H.Y., L.W.; X.Y. and Q.Z.; visualization, L.W.; supervision, H.Y.; project administration, H.Y. All authors have read and agreed to the published version of the manuscript.

Funding: This research received no external funding.

Conflicts of Interest: The authors declare no conflict of interest.

\section{References}

1. Kankanhalli, A.; Zuiderwijk, A.; Tayi, G.K. Open innovation in the public sector: A research agenda. Gov. Inf. Q. 2017, 34, 84-89. [CrossRef]

2. Etzkowitz, H.; Leydesdorff, L. The dynamics of innovation: From National Systems and "Mode 2" to a Triple Helix of university-industry-government relations. Res. Policy 2000, 29, 109-123. [CrossRef]

3. Leydesdorff, L.; Meyer, M. The scientometrics of a Triple Helix of university-industry-government relations (Introduction to the topical issue). Scientometrics 2007, 70, 207-222. [CrossRef]

4. Piirainen, K.A.; Andersen, A.D.; Andersen, P.D. Foresight and the third mission of universities: The case for innovation system foresight. Foresight 2006, 18, 24-40. [CrossRef] 
5. Johannsson, M.; Wen, A.; Kraetzig, B.; Cohen, D.; Liu, D.; Liu, H.; Palencia, H.; Wagner, H.; Stotesbury, I.; Jaworski, J.; et al. Space and Open Innovation: Potential, limitations and conditions of success. Acta Astronaut. 2015, 115, 173-184. [CrossRef]

6. Yun, J.J.; Zhao, X.; Yigitcanlar, T.; Lee, D.; Ahn, H. Architectural design and open innovation symbiosis: Insights from research campuses, manufacturing systems, and innovation districts. Sustainability 2018, 10, 4495. [CrossRef]

7. Chesbrough, H.; Kim, S.; Agogino, A. Chez Panisse: Building an open innovation ecosystem. Calif. Manag. Rev. 2014, 56, 144-171. [CrossRef]

8. Yun, J.H.; Park, K.B.; Gaudio, G.D.; Corte, V.D. Open innovation ecosystems of restaurants: Geographical economics of successful restaurants from three cities. Eur. Plan. Stud. 2020, 1-20. [CrossRef]

9. Yun, J.J.; Won, D.; Park, K.; Yang, J.; Zhao, X. Growth of a platform business model as an entrepreneurial ecosystem and its effects on regional development. Eur. Plan. Stud. 2017, 25, 805-826. [CrossRef]

10. West, J.; Bogers, M. Leveraging external sources of innovation: A review of research on open innovation. J. Prod. Innov. Manag. 2014, 31, 814-831. [CrossRef]

11. Bektaş, C.; Tayauova, G. A Model Suggestion for Improving the Efficiency of Higher Education: University-Industry Cooperation. Procedia-Soc. Behav. Sci. 2014, 116, 2270-2274.

12. Marques, J.P.; Caraça, J.M.; Diz, H. How can university-industry-government interactions change the innovation scenario in Portugal?-The case of the University of Coimbra. Technovation 2006, 26, 534-542. [CrossRef]

13. Zhou, W.; Li, Y.; Hsieh, C.J.; Chang, K.C.; Kiang, Y.J.; Ken, Y. Research Performance and University-Industry-Government Funding Sources in Taiwan's Technological and Vocational Universities. Innovation 2016, 18, 340-351. [CrossRef]

14. McAdam, M.; Debackere, K. Beyond 'triple helix' toward 'quadruple helix' models in regional innovation systems: Implications for theory and practice. RD Manag. 2018, 48, 3-6. [CrossRef]

15. Perkmann, M.; Walsh, K. University-industry relationships and open innovation: Towards a research agenda. Int. J. Manag. Rev. 2007, 9, 259-280. [CrossRef]

16. Inzelt, A. The evolution of university-industry-government relationships during transition. Res. Policy 2004, 33, 975-995. [CrossRef]

17. Poyago-Theotoky, J.; Beath, J.; Siegel, D.S. Universities and fundamental research: Reflections on the growth of university-industry partnerships. Oxf. Rev. Econ. Policy 2002, 18, 10-21. [CrossRef]

18. Jensen, M.B.; Johnson, B.; Lorenz, E.; Lundvall, B.Å.; Lundvall, B.A. Forms of knowledge and modes of innovation. Learn. Econ. Econ. Hope 2007, 155. Available online: https://ibrary.oapen.org/bitstream/handle/ 20.500.12657/31613/626406.pdf?sequence=1\#page=172 (accessed on 13 October 2020). [CrossRef]

19. Nam, G.M.; Kim, D.G.; Choi, S.O. How Resources of Universities influence Industry Cooperation. J. Open Innov. Technol. Mark. Complex. 2019, 5, 9. [CrossRef]

20. Chesbrough, H.W. Open Innovation: The New Imperative for Creating and Profiting from Technology; Harvard Business Press: Brighton, MA, USA, 2003.

21. Chesbrough, H.W. The era of open innovation. Manag. Innov. Chang. 2006, 127, 34-41.

22. Crescenzi, R.; Nathan, M.; Rodríguez-Pose, A. Do inventors talk to strangers? On proximity and collaborative knowledge creation. Res. Policy 2016, 45, 177-194. [CrossRef]

23. Tani, M.; Papaluca, O.; Sasso, P. The system thinking perspective in the open-innovation research: A systematic review. J. Open Innov. Technol. Mark. Complex. 2018, 4, 38. [CrossRef]

24. Yun, J.J.; Won, D.K.; Park, K.B. Entrepreneurial cyclical dynamics of open innovation. J. Evol. Econ. 2018, 28, 1151-1174. [CrossRef]

25. Yun, J.J.; Zhao, X.; Jung, K.; Yigitcanlar, T. The Culture for Open Innovation Dynamics. Sustainability 2020, 12, 5076. [CrossRef]

26. Shearmur, R.; Doloreux, D. How open innovation processes vary between urban and remote environments: Slow innovators, market-sourced information and frequency of interaction. Entrep. Reg. Dev. 2016, 28, 337-357. [CrossRef]

27. Vega-Jurado, J.; Gutiérrez-Gracia, A.; Fernández-de-Lucio, I. Does external knowledge sourcing matter for innovation? Evidence from the Spanish manufacturing industry. Ind. Corps Chang. 2009, 18, 637-670. [CrossRef]

28. Li, Y.R. The technological roadmap of Cisco's business ecosystem. Technovation 2009, 29, 379-386. [CrossRef] 
29. Granstrand, O.; Holgersson, M. Innovation ecosystems: A conceptual review and a new definition. Technovation 2020, 90, 102098. [CrossRef]

30. Jackson, D.J. What Is an Innovation Ecosystem? National Science Foundation: Alexandria, VA, USA, 2011.

31. Li, W.; Chang, J.; Wang, M.J.; Zhu, X.; Jin, A. Innovation 3.0 and innovation ecosystem. Stud. Sci. Sci. 2014, $32,1761-1770$.

32. Battistella, C.; Colucci, K.; De Toni, A.F.; Nonino, F. Methodology of business ecosystems network analysis: A case study in Telecom Italia Future Centre. Technol. Forecast. Soc. Chang. 2013, 80, 1194-1210. [CrossRef]

33. Brandenburger, A.M.; Nalebuff, B.J. Co-Opetition; Crown Business: New York, NY, USA, 2011.

34. Gobble, M.M. Charting the innovation ecosystem. Res.-Technol. Manag. 2014, 57, 55-59.

35. Adner, R. Match your innovation strategy to your innovation ecosystem. Harv. Bus. Rev. 2006, 84, 98. [PubMed]

36. Su, Y.S.; Zheng, Z.X.; Chen, J. A multi-platform collaboration innovation ecosystem: The case of China. Manag. Decis. 2018, 56, 87-104. [CrossRef]

37. Gassmann, O.; Enkel, E.; Chesbrough, H. The future of open innovation. RD Manag. 2010, 40, $213-221$. [CrossRef]

38. Ye, J.; Kankanhalli, A. Exploring innovation through open networks: A review and initial research questions. IIMB Manag. Rev. 2013, 25, 69-82. [CrossRef]

39. Lubienski, C. Innovation in education markets: Theory and evidence on the impact of competition and choice in charter schools. Am. Educ. Res. J. 2003, 40, 395-443. [CrossRef]

40. Yun, J.J.; Liu, Z. Micro and Macro Dynamics of Open Innovation with a Quadruple-Helix Mode. Sustainability 2019, 11, 3301. [CrossRef]

41. Howells, J.; Ramlogan, R.; Cheng, S.L. Universities in an open innovation system: A UK perspective. Int. J. Entrep. Behav. Res. 2012, 18, 440-456. [CrossRef]

42. Sun, S.L.; Zhang, Y.; Cao, Y.; Dong, J.; Cantwell, J. Enriching innovation ecosystems: The role of government in a university science park. Glob. Transit. 2019, 1, 104-119. [CrossRef]

43. Senge, P.M. The Art and Practice of the Learning Organization; Doubleday: New York, NY, USA, 1990.

44. Forrester, J.W. System dynamics, systems thinking, and soft OR. Syst. Dyn. Rev. 1994, 10, 245-256. [CrossRef]

45. Abreu, A.; Urze, P. System thinking shaping innovation ecosystems. Open Eng. 2016, 1. [CrossRef]

46. Yin, R.K. Case Study Research: Design and Methods; Sage Publications: London, UK, 2013.

47. Eisenhardt, K.M. Building theories from case study research. Acad. Manag. Rev. 1989, 14, 532-550. [CrossRef]

48. Leydesdorff, L. The Triple Helix of university-industry-government relations (February 2012). In Encyclopedia of Creativity, Innovation, and Entrepreneurship; Springer: New York, NY, USA, 2012; Available online: http://eprints.rclis.org/16559/1/The\%20Triple\%20Helix\%20of\%20University-Industry-Government\% 20Relations.Jan12.pdf (accessed on 13 October 2020).

Publisher's Note: MDPI stays neutral with regard to jurisdictional claims in published maps and institutional affiliations.

(C) 2020 by the authors. Licensee MDPI, Basel, Switzerland. This article is an open access article distributed under the terms and conditions of the Creative Commons Attribution (CC BY) license (http://creativecommons.org/licenses/by/4.0/). 